\section{Management to mitigate and adapt to climate change}

\author{
R. Lal, J.A. Delgado, P.M. Groffman, N. Millar, C. Dell, and A. Rotz
}

\begin{abstract}
Management decisions both at the field and off-site have the potential to contribute to climate change mitigation and adaptation. Climate change threatens to increase the potential for soil erosion, reduce soil quality, lower agricultural productivity and negatively impact food security and global sustainability, making it one of the most severe challenges we will face in the 21 st century. This paper looks at the potential of management to help us, not only mitigate climate change, but also to help us adapt to a changing climate. Different aspects of carbon management, nitrogen management, manure management, management in low-input systems (sustainable agriculture), and grazing land management are discussed as examples. Management decisions regarding conservation practices, such as no-till, conservation agriculture, and returning crop residue to the field to increase nutrient cycling, can contribute to carbon sequestration and help us mitigate and adapt to climate change. Additionally, management of grasslands, restoration of degraded/desertified lands, nitrogen management to reduce greenhouse gas emissions, precision conservation management at a field and/or watershed level, and other management alternatives can also help us mitigate and/or adapt to climate change. Management for climate change mitigation and adaptation is key for environmental conservation, sustainability of cropping systems, soil and water quality, and food security. This paper suggests, based on a review of the literature, that management decisions that reduce soil erosion, increase carbon sequestration to improve soil functions, soil quality, and soil health, and contribute to the resilience of soils and cropping systems will be needed to respond to climate change and related challenges such as food security. Our review suggests that without management decisions that increase soil and water conservation, food security for the world's growing population will be harder to achieve.
\end{abstract}

Key words: adaptation-carbon sequestration-climate change-managementmitigation-soil management

The purpose of this research editorial is to present a review of the scientific literature in order to start a conversation with the research community and the general public about how management decisions both on and off the field have the potential to contribute not only to climate change mitigation but to adaptation to climate change as well. One of our goals was to present key management areas that need to be considered when making these decisions, such as carbon (C) management, nitrogen (N) management, manure management, and grazing land management. However, other management areas that are not specifically covered in this review, such as agroforestry, buffer management, and others, could also be discussed, modified, or even refuted as cli-
This editorial aims to show that the human dimension of conservation, where a manager is analyzing and applying management decisions considering environmental, financial, and policy factors, is a key component of climate change mitigation and adaptation. Ultimately, it will be farmers, consultants, and others who will be applying management decisions at the field and/or watershed level for mitigation and adaptation to climate change. How policies, programs and other activities can encourage managers to apply the best decisions for climate change mitigation and adaptation is a complex topic worthy of discussion but is not explored in this editorial. Additionally, the related question of determining how programs and policies can be implemented to maximize agricultural production and soil and water conservation to help us achieve food security for the world's growing population is also set aside. Instead, this editorial focuses on how management decisions can contribute to climate change mitigation and adaptation by selecting and using practices that reduce erosion and contribute to the maintenance of long-term agricultural productivity as new climate challenges are faced. It also seeks to point out that, as shown by our review of the literature, management decisions that maximize agricultural production and minimize environmental impacts to soil and water quality, in addition to helping us mitigate climate change and adapt to its effects, will contribute to long-term sustainability and future food security.

It is widely recognized that anthropogenic activities are responsible for the observed and projected climate change (Gleick et al. 2010; IPCC 2006; Ramanathan and Xu 2010). The US Secretary of Agriculture Tom Vilsack has reported that "climate change is one of the greatest threats facing our planet" (USDA NRCS 2010). Several scientists have

Rattan Lal is a professor in the School of Environment \& Natural Resources at The Ohio State University, Columbus, Ohio. Jorge A. Delgado is a soil scientist for the USDA Agricultural Research Service (ARS), Fort Collins, Colorado. Peter $\mathbf{M}$. Groffman is a microbial ecologist at the Cary Institute of Ecosystem Studies, Milbrook, New York. Neville Millar is a senior research associate at the Kellogg Biological Station, Michigan State University, East Lansing, Michigan. Curtis J. Dell is a soil scientist and Alan Rotz is an agricultural engineer for the USDA ARS, University Park, Pennsylvania. 
reported on the connection between climate change, soil and water resources, and population growth, and have noted that these issues will pose severe challenges that can potentially impact food security (Montgomery 2007; Lal 2002; Verdin et al. 2005; Bryan et al. 2009; Morton 2007). Godfrey et al. (2010) reported that it will be a challenge to feed the nine billion people projected to soon live on our planet. Implementing management decisions that maximize agricultural production and increase yields while conserving soil and water quality and mitigating and/or adapting to climate change, will be important in helping to address this century's emerging food security issues. Management decisions both on and off the field have the potential to contribute to climate change mitigation and adaptation. For example, management decisions about soil C, an element that is tied to soil quality functions (Doran and Jones 1996), can contribute to conservation and $C$ sequestration. Additionally, $\mathrm{N}$ management that considers the $\mathrm{N}$ cycle and the potential to reduce direct and indirect emissions of nitrous oxide $\left(\mathrm{N}_{2} \mathrm{O}\right)$ can also contribute to climate change mitigation and adaptation. Croplands, grasslands, riparian zones and wetlands, as well as long-term data assessing spatial and temporal variability, and watershed-system analysis are important considerations when developing large-scale and/ or long-term management plans. Sustainable land management and efforts to restore degraded lands can also contribute to climate change mitigation and adaptation.

There are different types of agricultural systems around the globe, ranging from highly intensive agricultural systems to lowintensity ones. Whether the system under consideration is a highly-intensive system where even modeling evaluations are conducted or a small farming operation under low-intensity agriculture, the best management decisions for maximizing conservation and mitigating and adapting to climate change while considering the site-specific situation need to be applied.

This latter point about taking the site-specific situation into consideration is a key one. It is important to stress that management, as it is discussed in this editorial, refers not only to the specific practices that may be employed by the farmers or managers but also more generally to the decision-making process the managers must go through as they determine what practices are best suited for the conditions specific to their sites or fields. For those seeking more detailed information on particular practices, a thorough review of specific conservation practices and their potential roles in climate change mitigation and adaptation can be found in Delgado et al (2011). In addition to discussing select conservation practices, the Delgado et al. (2011) review of the literature also shows that good policies that promote the implementation of conservation practices to mitigate and adapt to climate change will contribute to future food security, while a lack of good policies and/or the implementation of bad policies will not, and may even increase the negative impacts of climate change on limited soil and water resources.

\section{Management for Mitigation and Adaptation}

Carbon Management. The terrestrial C pool has been a source of atmospheric carbon dioxide $\left(\mathrm{CO}_{2}\right)$ ever since the beginning of settled agriculture (Ruddiman 2003). Conversion of natural systems to agricultural ecosystems (e.g., croplands, grazing lands) often leads to depletion of the terrestrial C pool because of deforestation, biomass burning, drainage, and soil cultivation. In general, relatively less biomass $\mathrm{C}$ is returned to the soil in agricultural ecosystems than in natural ecosystems, although there may be exceptions to this generality. For example, for a desert site that is a water and N-limited system, if irrigation and $\mathrm{N}$ fertilizer are added, the biomass $\mathrm{C}$ returned may be higher for the managed system. In general, the rate of decomposition of soil organic matter (SOM) is greater in managed than natural ecosystems because of changes in soil temperature, moisture regimes, and soil disturbance, and water and wind erosion could also contribute to the transportation of SOM off site. For the top surface layer (the top $15 \mathrm{~cm}$ [5.9 in]), most agricultural soils lose about $50 \%$ of their antecedent soil organic carbon (SOC) pool in about 25 to 50 years after conversion from natural ecosystems in temperate climates and in about 5 to 10 years in tropical regions (Lal 2004). Because most agricultural soils have a lower SOC pool than their natural counterparts under undisturbed conditions, these soils can be managed to enhance their SOC pool by humification of a part of the net primary production (biomass-C) returned to the soil. The SOC sink capacity of agricultural soils, created by the historic depletion of the SOC pool, can be regenerated through conversion to a restorative land use and adoption of those soil and crop management practices, which create a positive $\mathrm{C}$ budget.

Land area affected by a range of soil degradation processes (erosion, salinization, nutrient depletion, acidification, pollution, and minelands) may be as much as 3.5 billion hectares or Bha ( 8.6 billion acres) (Bai et al. 2008). Eroded and degraded soils lose a large amount of surface SOC that is transported off site due to the erosion process and/or lower net primary production, which contributes to reductions in the amount of biomass $\mathrm{C}$ that is returned to the surface soil. Because these soils are then mostly depleted of their SOC pool, the ecosystem C sink capacity of these lands is higher than soils of other ecosystems. Globally, land area prone to soil erosion by water (1,094 million hectares [Mha] [2,702 million ac]) and wind (549 Mha [1,356 million ac]) is the largest (Oldeman and van Lynden 1998) among all degradation processes. Thus, realizing even a fraction of the total technical potential to restore eroded and erosion-prone soils may avoid depletion of the SOC pool (Lal 2003). Salt-affected soils cover an area of 956 Mha (2,361 million ac), of which 56 Mha (138 million ac) include areas affected by secondary salinization caused by inappropriate irrigation (Lal 2010). Across the globe, there is a great potential for $\mathrm{C}$ sequestration through reclamation of salt-affected soils and through desertification control (Lal 2001), as well as reclamation of mine soils (Shrestha et al. 2009).

Rather than being a source and a cause of the problem, agricultural ecosystems can be a sink of atmospheric $\mathrm{CO}_{2}$ and reduce greenhouse gases $(\mathrm{GHG})$ through the adoption of sustainable land management options (figures 1,2). A sustainable land management system is defined as a knowledge-based combination of technologies, policies, and practices that integrate land, water, biodiversity, and environmental factors to meet rising food and fiber demands, while sustaining ecosystem services and livelihood (World Bank 2006). Some promising sustainable land management options for enhancing net primary production, increasing the ecosystem $\mathrm{C}$ pool, reducing GHG, and off-setting anthropogenic emissions by $\mathrm{C}$ sequestration in soils and biota are no-till, cover crops, biochar, improving $\mathrm{N}$ management (e.g., controlled- 


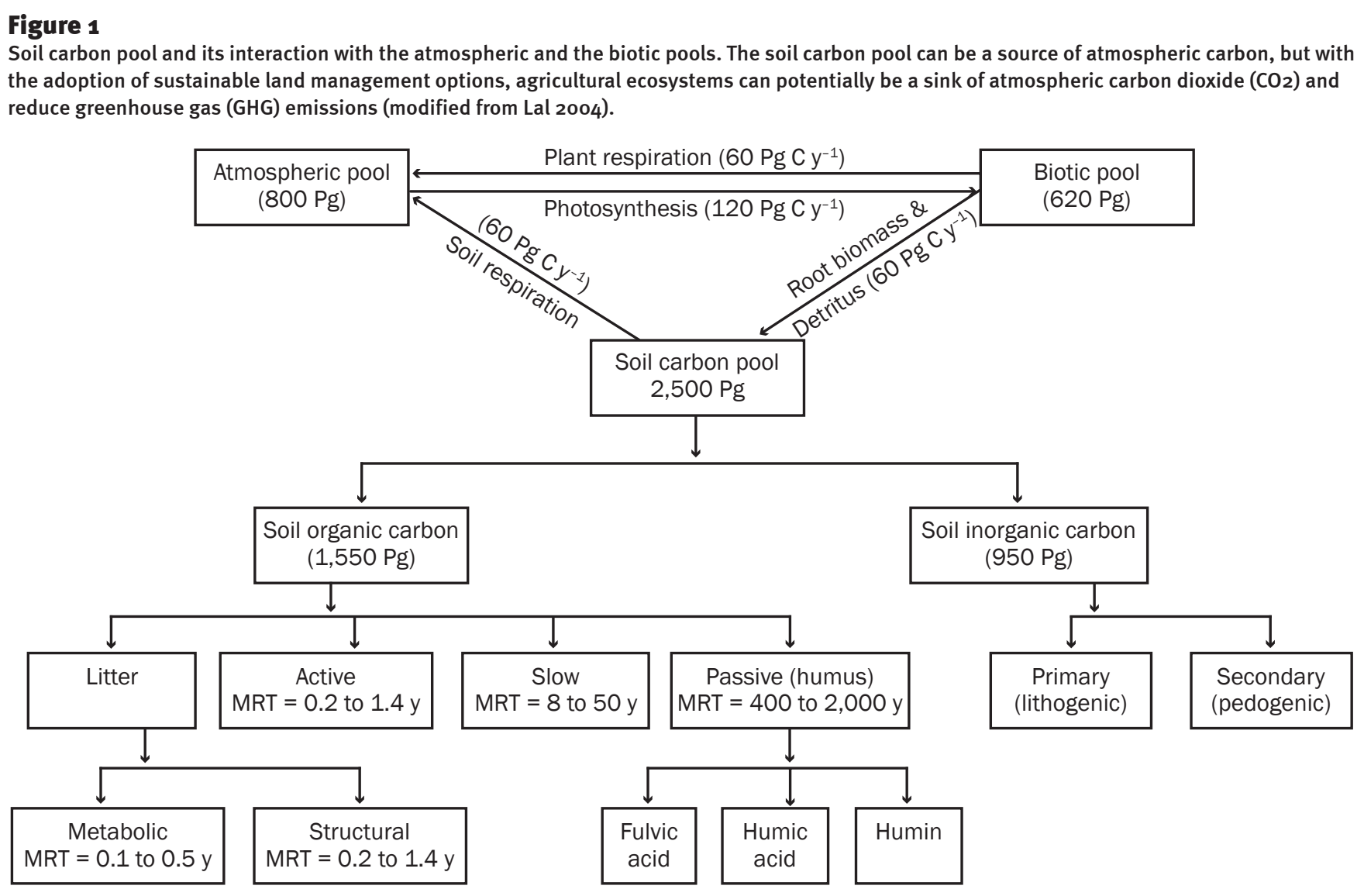

Note: $\mathrm{MRT}=$ mean residence time

release fertilizer, increasing $\mathrm{N}$ cycling), and others (Lal 2001, 2003). Lands that may have a large C sink capacity include degraded/ desertified lands, croplands, grazing lands, forest lands, riparian zones, and wetlands.

Despite the availability of research data beginning 50 years ago regarding the conservation-effectiveness of no-till farming, the rate of adoption of no-till farming is low. Global land area under no-till farming is approximately 117 Mha (289 million ac) or about $7 \%$ of the world cropland area (Kassam et al. 2009; Derpsch 2011). No-till farming is mostly adopted on a large scale and on mechanized farms in countries such as the United States (26.5 Mha [138 million ac]), Argentina (25.8 Mha [65.5 million ac]), Brazil (25.5 Mha [63.0 million ac]), Australia (17.0 Mha [42.0 million ac]), Canada (13.5 Mha [33.3 million ac]), Paraguay (2.4 Mha [5.9 million ac]), China (1.3 Mha [3.2 million ac]) and Kazakhstan (1.3 Mha). Countries such as Bolivia, Uruguay, Spain, South Africa, Venezuela, France, Finland, Chile, New Zealand, and Colombia have no-till areas ranging from 0.7 to $0.1 \mathrm{Mha}$ (1.7 to 0.3 million ac). There are several social, political, and cultural reasons for no or poor adoption of no-till farming in developing countries. Competing and multiple uses of crop residues (e.g., feed, fuel, fencing material) is one factor. Land tenure and ownership rights may be another, and lack of availability of essential inputs (e.g., herbicides, no-till seeder) or prohibitively high costs of these inputs may be yet another factor. Addressing these issues concerning the social, political, and cultural factors that limit technological adoptions in developing countries must be a high priority for policymakers, researchers, and producers.

Nitrogen Management. Nitrogen is central to living systems and is a primary constituent of nucleotides and proteins in plants, animals, and microorganisms, regulating numerous essential ecological and biogeochemical processes (figure 3). Due to the increase in fossil fuel combustion and a growing demand for $\mathrm{N}$ in agriculture and industry, there has been a dramatic increase in biologically available (reactive) $\mathrm{N}$ in the biosphere (Cowling et al. 2002; Galloway et al. 2003). This demand and the perva- sive inefficiencies in $\mathrm{N}$ use (Galloway et al. 2008; Delgado et al. 2010b) have, in some instances, come at a significant societal cost through increased losses of nitrous oxide $\left(\mathrm{N}_{2} \mathrm{O}\right)$, nitric oxide $(\mathrm{NO})$, ammonia $\left(\mathrm{NH}_{3}\right)$, and nitrate $\left(\mathrm{NO}_{3}\right)$ and increased deposition of N (Mosier 2001; Mosier et al. 2002), contributing to well-documented environmental degradation, including increased coastal hypoxia, acidification of aquatic and soil systems, eutrophication, and atmospheric warming (Cowling et al. 2002; Galloway et al. 2003; IPCC 2006). Nitrate leaching from tile systems has been reported as a key mechanism contributing to the $\mathrm{N}$ loads that worsen the hypoxia issue in the Gulf of Mexico (Mitsch et al. 2001). Nitrate leaching also contributes to increased concentrations of $\mathrm{N}$ in groundwater (Follett 1989; Li et al. 2007; Lavado et al. 2010). Additionally, reactive $\mathrm{N}$ has been reported to have impacts on human health (USEPA 1989; Eichholzer and Gutzwiller 1998; Follett et al. 2010) and biodiversity (Bobbink et al. 2010; Vitousek et al. 1997).

On the other hand, the synthetic production of fertilizer $\mathrm{N}$ and its inputs to 


\section{Figure 2}

Sustainable land management (SLM) options to increase net primary production and ecosystem soil organic carbon (SOC) pool to mitigate climate change.

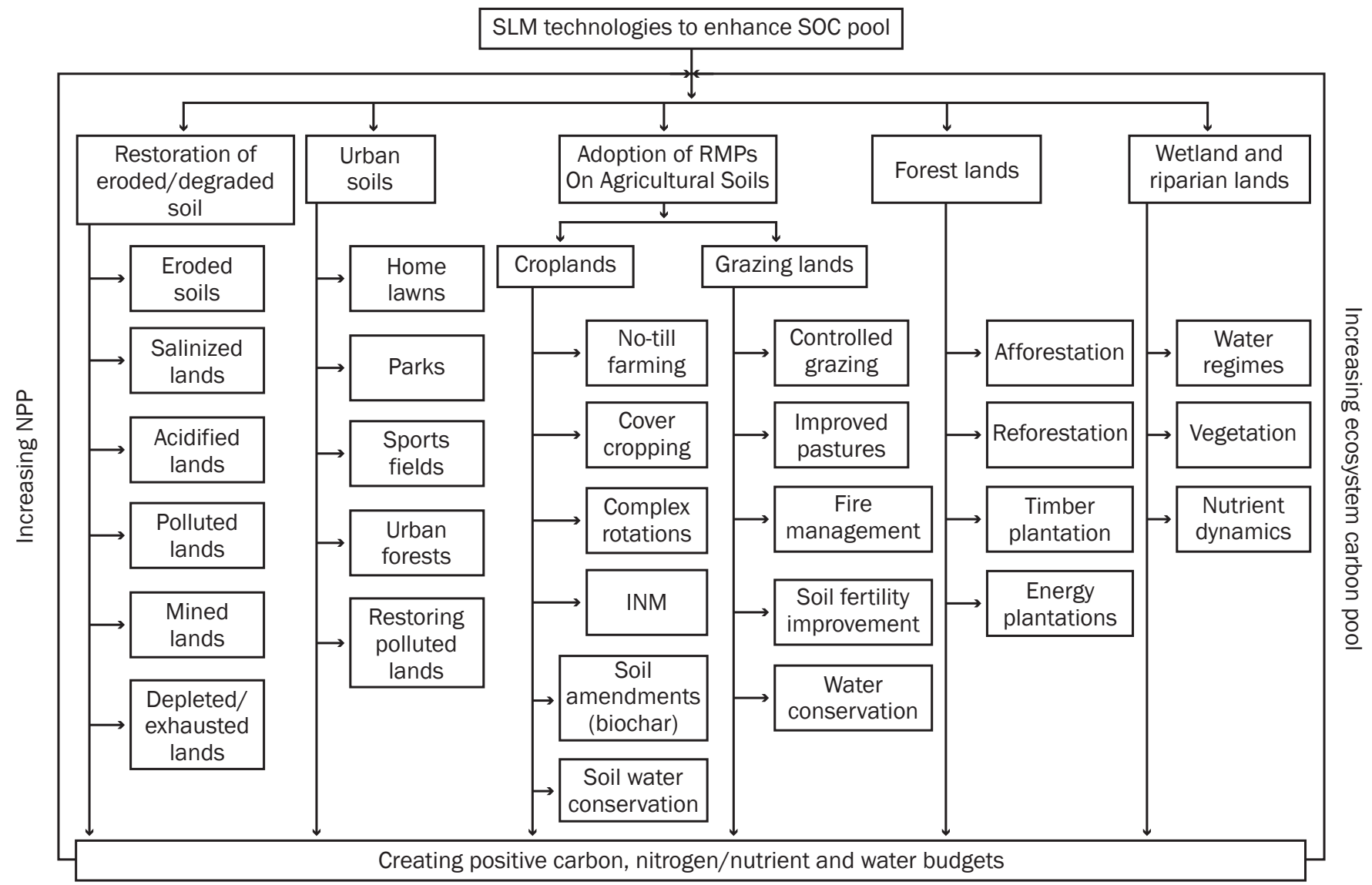

Notes: RMPs = recommended management practices. INM = integrated nutrient management. NPP = net primary productivity .

cropping systems have helped humankind increase global food production to meet the increased demands that are generated with population growth (Robertson and Vitousek 2009). Although $\mathrm{N}$ inputs are needed to maximize food production and they contribute to food security, $\mathrm{N}$ inputs to agricultural systems/cropland soils contribute to increased $\mathrm{N}$ losses via atmospheric, surface, and/or leaching pathways. These $\mathrm{N}$ inputs contribute to increases in direct emissions of $\mathrm{N}_{2} \mathrm{O}$, a potent GHG (IPCC 2006; Mosier et al. 1991). Additionally, other loss pathways for $\mathrm{N}$, such as $\mathrm{NO}_{3}$ leaching and $\mathrm{NH}_{3}$ volatilization, also contribute to increases in indirect emissions of $\mathrm{N}_{2} \mathrm{O}$ (IPCC 2006).

Numerous management technologies have been proposed to mitigate $\mathrm{N}$ losses from agricultural systems and hence reduce the immediately available pool of reactive N. Meisinger and Delgado (2002) and Robertson and Vitousek (2009) reviewed the strategies to improve $\mathrm{N}$-use efficiency in annual cropping systems. These strategies can be grouped as (1) use cropping system tools (e.g., use of deeper-rooted crops to improve use of soil resources, introduction of a scavenger crop into a rotation to recover nitrate leached from shallower-rooted crops, and/or addition of a legume to a crop rotation); (2) understand the soil-crop-hydrologic cycle and use this knowledge to better manage $\mathrm{N}$ and irrigation (e.g., use of computer models to conduct site-specific assessments of the nitrogen and water cycles to improve nitrogen and water use efficiencies); (3) improve management of timing, placement, and formulation of fertilizer $\mathrm{N}$ so that it is applied at a time and location that allows quick utilization by the crop; and (4) manage watersheds to mitigate losses of reactive $\mathrm{N}$. The underpinning principles of $\mathrm{N}$ fertilizer best management pratices are to apply the correct nutrient in the amount needed, with an application that is timed and placed to meet crop demand, i.e., right rate, right type, right timing, right placement (4Rs; Snyder et al. 2007). Nitrification inhibitors (Bronson and Mosier 1993) and controlled-release fertilizers (Delgado and Mosier 1996; Snyder et al. 2009) have also shown potential for increasing soil retention and plant recovery of applied fertilizer $\mathrm{N}$, as well as for minimizing emissions of $\mathrm{N}_{2} \mathrm{O}$.

Manure Management. The relationship between land-application of manure and GHG emission balances is not clearly understood. In the cases of minimum tillage or grasslands, manure injection appears to be the best overall management practice for method of application, but further research is needed to determine to what extent injection could increase $\mathrm{N}_{2} \mathrm{O}$ or methane $\left(\mathrm{CH}_{4}\right)$ emissions and offset gains in $\mathrm{C}$ sequestration that can be achieved through conservation programs. More information is needed to determine 


\section{Figure 3}

Nutrient cycles for key essential elements needed for crop production and their fate and transport in the environment (from Delgado and Follett [2002]).

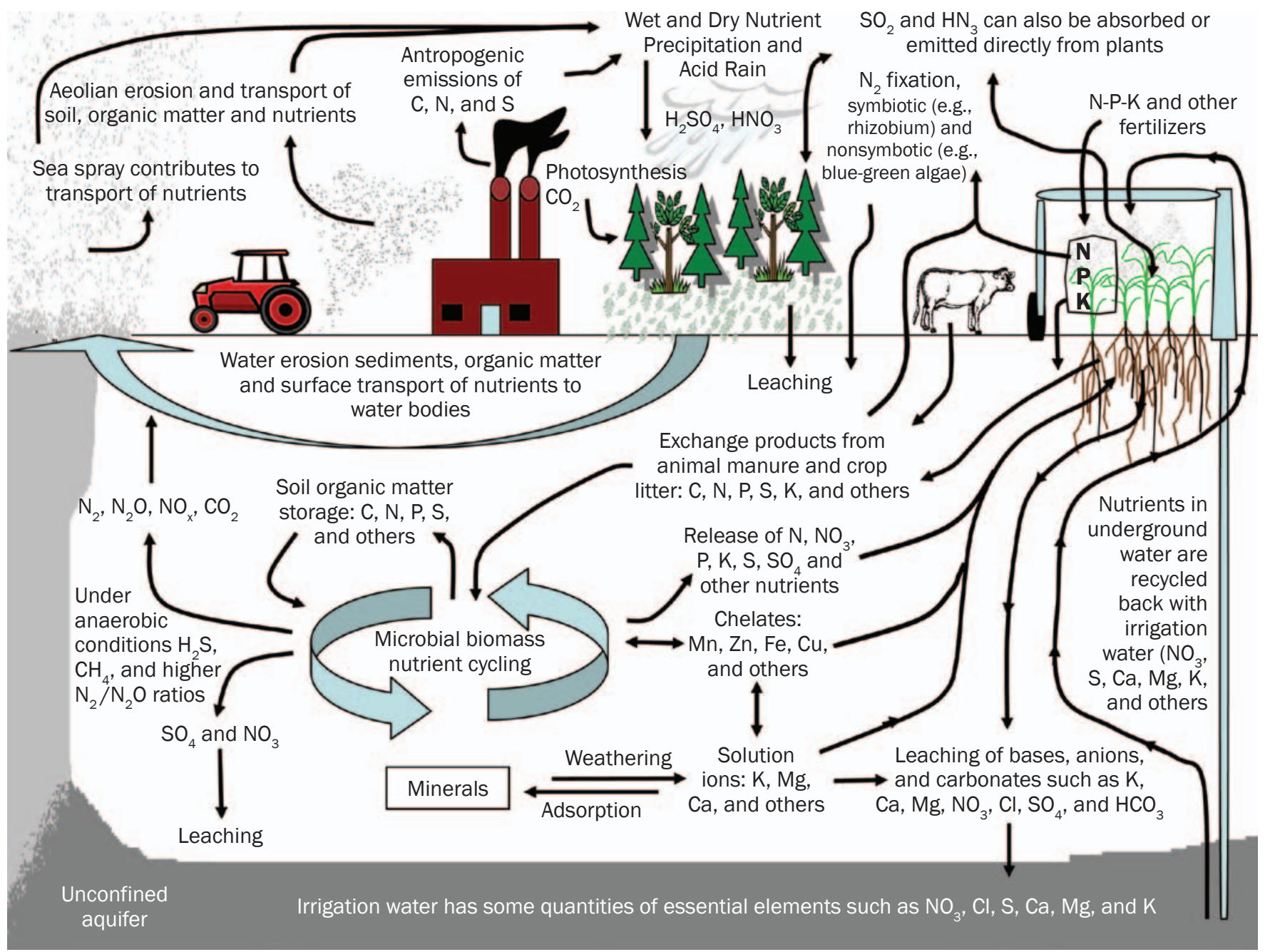

Notes: $\mathrm{C}=$ carbon. $\mathrm{N}=$ nitrogen. $\mathrm{S}=$ sulfur. $\mathrm{CO}_{2}=$ carbon dioxide. $\mathrm{H}_{2} \mathrm{SO}_{4}=$ sulfuric acid. $\mathrm{HNO}_{3}=$ nitric acid. $\mathrm{N}_{2}=$ dinitrogen. $\mathrm{SO}_{2}=$ sulfur dioxide. $\mathrm{NH}_{3}=$ ammonia. $\mathrm{P}=$ phosphorus. $\mathrm{K}=$ potassium. $\mathrm{N}_{2} \mathrm{O}=$ nitrous oxide. $\mathrm{NO}_{x}=$ nitrogen oxides. $\mathrm{NO}_{3}=$ nitrate. $\mathrm{SO}_{4}=$ sulfate. $\mathrm{H}_{2} \mathrm{~S}=$ hydrogen sulfide. $\mathrm{CH}_{4}=$ methane. $\mathrm{Mn}=$ manganese. $\mathrm{Zn}=$ zinc. $\mathrm{Fe}=$ iron. $\mathrm{Cu}=$ copper. $\mathrm{Ca}=$ calcium. $\mathrm{Mg}=$ magnesium. $\mathrm{Cl}=$ chloride. $\mathrm{HCO}_{3}=$ bicarbonate.

how aeration, water content, nitrification rates, and other processes affect $\mathrm{N}_{2} \mathrm{O}$ production associated with manure injection. Additionally, Taghizadeh-Toosi et al. (2011) reported that biochar reduced emissions of $\mathrm{N}_{2} \mathrm{O}$ from urine patches; however, more research is needed on the potential use of biochar to reduce GHG emissions from manure and/or grazing systems.

Management in Low-Input Systems (Sustainable Agriculture). The impacts of climate change on low-input/subsistence agricultural systems will be significant (Verdin et al. 2005; Montgomery 2007; Morton 2007). The effects of climate change on temperature, weather variability, extreme events, snow caps-which provide water for a sustainable irrigation system-and other factors, will greatly impact this type of agriculture (Morton 2007). These challenges will need to be assessed and managed by small farmers of sustainable systems across the globe. Lal (2002) recommended several strategies for increasing soil $\mathrm{C}$ sequestration for dryland ecosystems of West Asia and North Africa, including residue management, cover crops, crop rotations, and other management options. These strategies are a win-win situation because they contribute to the improvement of soil quality and enhance soil productivity (Lal 2002). Not only can these management strategies increase C sequestration and contribute to lower risk of soil erosion, soil degradation, and land desertification, but these management decisions that aim to help low-input/subsistence systems mitigate climate change can also have a role in adaptation.

Since erosion reduces soil productivity, and in conventional agriculture soil erosion occurs at a higher rate than soil formation, soil erosion threatens to undermine the foundation of civilization by reducing soil productivity (yields) at a time when the world is confronted with a large, growing 
population that requires a larger food supply (Montgomery 2007). The consequences of erosion are of even more concern now that we are confronted by climate change, as it has been reported that climate change and extreme events could increase erosion rates (Nearing et al. 2004; Hatfield and Prueger 2004). As they are confronted by this challenge, societies will have to prioritize management decisions to minimize erosion, since this will be necessary to increase yields per unit of land.

Conservation agriculture as defined by the Food and Agriculture Organization of the United Nations (FAO 2009), provides alternatives that can address not only some of the challenges posed by erosion, but also some of the challenges presented by climate change and the high energy costs projected for the future. The FAO principles of conservation agriculture, including minimal disturbance of soils while providing continuous plant residue cover and using diverse rotations and/or cover crop systems, are also in sync with management options that can be used to sequester $\mathrm{C}$ and to help mitigate and adapt to climate change. These FAO (2009) principles of conservation agriculture could be applied across the globe wherever they are viable and applicable, independent of whether they are being applied to a low-intensity or highintensity agricultural system. For example, in Africa, intensive agriculture applied by small farmers was degrading soil productivity to the point that grain yields were lower than $1 \mathrm{t} \mathrm{ha}^{-1}\left(0.446 \mathrm{tn} \mathrm{ac}^{-1}\right)$; with the implementation of conservation agriculture practices with improved crop rotations and minimum soil disturbance, the reduction in yields in these systems was reversed, and higher yields are now being obtained by the farmers (Thiombiano and Meshack 2009). Silici (2010) also reported similar results after working with small farmers from The Kingdom of Lesotho, where conservation agriculture contributed to lower erosion, enhanced soil fertility, and increased agricultural productivity. These results show that even for small farming systems with low inputs, conservation agriculture and management decisions that contribute to $\mathrm{C}$ sequestration, such as minimum soil disturbance, crop residue management, and crop rotation management, will help small farmers mitigate and adapt to climate change.

Grazing Land Management. Grazing land and pasture cover about 3.4 Bha (8.4 billion ac) globally and 219 Mha (541 million ac) in the United States (Gurian-Sherman 2011). This large total area suggests that grazing lands could have a potential role in climate change mitigation and adaptation; however, there is need for additional research on how GHG emissions may be affected by grazing land and pasture management (Gurian-Sherman 2011). Gurian-Sherman (2011) reported that there is potential to use grazing land and pasture management to reduce $\mathrm{CH}_{4}$ emissions by diversifying pasture species and planting legumes. Additionally, some studies suggest that grazing land and pasture also have the potential to contribute to reduced $\mathrm{N}_{2} \mathrm{O}$ emissions (Gurian-Sherman 2011). Recently, Taghizadeh-Toosi et al. (2011) reported that biochar may be a tool to reduce $\mathrm{N}_{2} \mathrm{O}$ emissions from ruminant urine patches; however, there is a need for additional research on biochar and $\mathrm{N}_{2} \mathrm{O}$ emissions from pasture systems. Use of well-managed pasture systems generally benefits soil quality. The primary benefit is the buildup of SOM and the sequestering of C (Franzluebbers and Follett 2005; Gurian-Sherman 2011). Rotated cropland generally maintains lower levels of SOM compared to perennial grassland. Additional research that includes a whole system analysis is needed to achieve better understanding of how grazing management may affect GHG emissions (Del Grosso 2010).

Riparian Zones and Wetlands. Riparian zones are an essential component of management of agricultural nonpoint source pollution. Work in the 1970 s discovered that these areas had the capacity to "buffer" upland agricultural land uses, absorbing nutrients moving from upland fields, preventing movement to streams, and improving overall watershed ecosystem environmental performance (Lowrance et al. 1984; Peterjohn and Correll 1984; Jacobs and Gilliam 1985). Riparian zones are particularly effective "sinks" for groundwater-borne $\mathrm{NO}_{3}$ (Hill 1996) and are an essential component of efforts to reduce $\mathrm{N}$ delivery to receiving waters in many parts of the world (Lowrance et al. 1997; Mitsch et al. 2001). The main processes underlying the $\mathrm{N}$ sink capacity of riparian zones are denitrification, the anaerobic microbial conversion of $\mathrm{NO}_{3}$ into the gases $\mathrm{NO}, \mathrm{N}_{2} \mathrm{O}$, and $\mathrm{N}_{2}$, and plant $\mathrm{N}$ uptake ( $\mathrm{N}$ content in plant aboveground, belowground, and residue compartments). The IPCC developed a methodology to account for emissions of $\mathrm{N}$ gases (Groffman et al. 1998; Mosier et al. 1998), based on the assumption that fertilizer applied to crop fields moves through the environment from surface soils, to groundwater, to rivers, to estuaries, and ultimately to the ocean, with $\mathrm{N}_{2} \mathrm{O}$ emissions at each point along the way (Groffman et al. 2000; Nevison 2000). Measuring fluxes across the landscape and verifying the methodology has been difficult, however, and the magnitude of these "indirect $\mathrm{N}_{2} \mathrm{O}$ emissions" has recently been revised downward (Reay et al. 2005; Reay et al. 2009). This revision was based on studies from diverse regions and suggests that riparian zones and other areas downstream of agricultural fields are not major sources of $\mathrm{N}_{2} \mathrm{O}$ in regional GHG budgets (Reay et al. 2003; Sawamoto et al. 2005; Kim et al. 2009a, 2009b). Managing riparian zones to keep them in permanent vegetation, especially forests, will increase $\mathrm{C}$ sequestration in soils and vegetation (Lal 2005), and nutrient inputs can increase this sequestration (Fortier et al. 2010).

Long-Term Assessments and Spatial and Temporal Variability. Programs such as the Green House Gas Reduction through Agricultural Carbon Enhancement network (GRACEnet) and the Conservation Effects Assessment Project (CEAP) are key national programs (approaches) helping to monitor the long-term effects of conservation practices (Jawson et al. 2005; Mausbach and Dedrick 2004). The monitoring system GRACEnet is a multilocation field study with standardized protocols that monitors net GHG emissions $\left(\mathrm{CO}_{2}, \mathrm{~N}_{2} \mathrm{O}, \mathrm{CH}_{4}\right)$ and $\mathrm{C}$ sequestration. This study will provide important information that will contribute to the decision-making process as best conservation practices for climate change adaptation and mitigation are established. The CEAP Watershed Assessment Program is a key long-term program that complements GRACEnet (Mausbach and Dedrick 2004). The CEAP program is contributing to the long-term evaluation of the effects of conservation practices on water quality and erosion. Both CEAP and GRACEnet will help provide datasets that are needed for the calibration and validation of tools to assess the long-term effects of conservation practices while accounting for spatial and temporal variability.

Watershed analysis can help assess how conservation practices and management decisions can reduce environmental impacts 
on a larger scale and can help assess the contributions of these practices to soil and water quality conservation (Richardson et. al 2008). For example, the Soil and Water Assessment Tool (SWAT) can be used to assess the benefits of applying a series of management practices across a watershed and what the total reduction in $\mathrm{NO}_{3}$ leaching will be across the watershed (Osmond 2010). As another example, Brooks et al. (2010) reported that there has been a decrease in sediment loads over the last 28 years in the Paradise Creek watershed, which can be attributed to a conversion from conventional tillage systems to minimum tillage and perennial grasses. In another watershed, Jha et al. (2010) conducted an analysis using the SWAT model and reported that targeting land-use change can contribute to reductions in $\mathrm{NO}_{3}$ leaching in the watershed by converting row crops in highly erodible lands to grass cover systems. There is potential to use models to assess variability at the watershed level to target applications of conservation practices such as riparian buffers, wetlands, sediment ponds, and other practices to conserve water quality (Berry et al. 2003; Walter et al. 2007; Delgado and Berry 2008; Tomer 2010).

\section{Discussion and Conclusions}

The future of food security is questionable due to the increased demands that will come from population growth and the potential impacts of climate change on agricultural production. We propose that soil management can be one of our best tools for climate change mitigation and adaptation. If we are going to be able to handle the challenges that come with climate change, we will need to maximize soil and water conservation via soil management to increase agricultural food production per unit of land. The way we manage soils and crop residue now will have an impact on the quality of soil and water resources that future generations will need for food security. It is imperative that we improve management if we are to have food security for civilization.

Soil management can contribute to a safety net for future generations, but we need to minimize soil erosion and the threat of the potentially greater soil erosion that may come with climate change. Increasing $\mathrm{C}$ and $\mathrm{N}$ sequestration with policies and practices that we have in our management toolbox, such as applying conservation agriculture, using cover crops, keeping the soil covered with residue, using crop rotations, or returning crop residue, will improve soil quality and will help minimize soil erosion. As these tools are applied, however, managers need to stay mindful of site-specific conditions and incorporate these factors when making management decisions, including those about which tools to apply.

Soil management can be used to mitigate climate change because soils can sequester large quantities of atmospheric $\mathrm{C}$ across world agroecosystems. Additionally, $\mathrm{C}$ sequestration could be an effective tool to help us adapt to climate change or extreme weather events. Sequestering $\mathrm{C}$ will increase SOM and water holding capacity, which can increase the likelihood of the crops being able to tolerate drier conditions, especially if drought-tolerant varieties are used, which could increase water storage in a future of expected higher air temperatures and evapotranspiration. Higher SOM and better aggregate structure would also allow soils to have a higher drainage capacity.

Soil management will also help us adapt to changes in climate by minimizing erosion, which will be essential because crops grown on productive soils with a deeper soil profile can store more water and have a larger zone for roots to grow, enabling them to access larger quantities of water and nutrients. In other words, soils that are under management practices/systems that reduce erosion and contribute to $\mathrm{C}$ sequestration will help crops better adapt to climate change and extreme events than degraded soils. This is also why it is so important to implement management decisions that contribute to the restoration of degraded/desertified lands. Soil management to add C, which contributes to so many beneficial soil functions, will be needed to maintain and/or improve soil quality. Conservation agriculture efforts by small farmers who are managing low-input systems are efforts in the right direction; they contribute to climate change mitigation by sequestering $\mathrm{C}$, and by improving the soil productivity, these efforts also improve the opportunities of small farmers to adapt to climate change.

Grazing management, use of buffers, and management decisions that conserve riparian zones and wetlands are tools in our management toolbox that can help us mitigate and adapt to climate change.Additionally, wetlands and riparian forest areas will be very important in helping us reduce the environmental impacts of extreme events. The concepts of precision/target conservation and considering spatial and temporal variability are also among the available tools to increase the efficiency/impact of conservation practices at a field and/or watershed level. With precision conservation, we could assess which areas in the watershed may be better for establishing riparian zones and/or wetlands to maximize environmental benefits and $\mathrm{C}$ sequestration, especially in the case of permanent vegetation of riparian forest.

Nitrogen management can also be a key component in the mitigation of climate change because emissions of $\mathrm{N}_{2} \mathrm{O}$ from the agricultural sector are significant. There is potential to use nitrification inhibitors, controlled-release fertilizers, and practices that help increase $\mathrm{N}$ use efficiency and reduce $\mathrm{N}$ inputs and net emissions of $\mathrm{N}_{2} \mathrm{O}$ to mitigate climate change. Additionally, sequestering $\mathrm{N}$ and $\mathrm{C}$ in SOM and increasing $\mathrm{N}$ cycling, along with implenting other conservation practices, such as using cover crops or including a leguminous crop in the rotation, increases the potential for soils to cycle more $\mathrm{N}$.

Research, databases, and models help us understand the long-term effects of these systems. Programs like CEAP and GRACEnet are good examples of how databases can be used to help managers assess the effects of conservation practices and implement management decisions that help us mitigate and adapt to climate change, while also benefiting from other effects such as improved water quality. Although we could list a large set of research needs, one of the current research needs is to continue looking for methods to improve soil management for increased C sequestration (e.g., research on the potential to use biochar from energy processes as a soil amendment at larger scales). In $\mathrm{N}$ management, additional research is needed on the potential use of new controlled-release fertilizers, nitrification inhibitors, and/or other approaches to reduce $\mathrm{N}_{2} \mathrm{O}$ emissions. Manure research, including research on its potential use as a biogas, and research on other management alternatives that may provide energy and cycle $\mathrm{C}$ and $\mathrm{N}$ to soils with minimal environmental impacts is also needed. Further research into developing viable biofuel energy systems that have minimal impacts to soil and water quality and also sequester C (e.g., switchgrass) is important as well. This short list is just a few examples, but in general there is a need for research towards develop- 
ing systems and management approaches that increase agricultural production of food, fiber, and energy while maximizing soil and water conservation; developing such systems and approaches will contribute to climate change mitigation and adaptation.

Nutrient managers (e.g., farmers, consultants) will likely need to select across a variety of technologies, strategies, decision support tools, and management alternatives (e.g., cover crops, source of $\mathrm{N}$ ), while considering site-specific information and environmental, financial, and policy factors, to develop the best solutions that maximize yields and reduce losses of reactive $\mathrm{N}$. If crop residue in the soil system is incorporated and/or left in the system, $\mathrm{C}$ sequestration potential can be increased, and $\mathrm{N}$ cycling can potentially increase as organic matter increases, which may reduce the amount of $\mathrm{N}$ that needs to be added (especially if cover crops and/ or leguminous crops are introduced into the rotation). Management decisions that incorporate conservation practices that help us adapt to extreme events are key to reducing the potential for erosion. Management of off-site conservation practices, such as buffers, riparian zones, and wetlands, can provide additional ecosystem services, such as sequestering $\mathrm{C}$ and removing $\mathrm{N}$ from the environment. Management decisions that help us mitigate and adapt to climate change will be key to conservation, the sustainability of cropping systems, soil and water quality, and food security.

\section{References}

Bai, Z.G., D.L. Dent, L. Olsson, and M.E. Schaepman. 2008. Proxy global assessment of land degradation. Soil Use and Management 24(3):223-234.

Berry, J.R., J.A. Delgado, R. Khosla, and FJ. Pierce. 2003. Precision conservation for environmental sustainability. Journal of Soil and Water Conservation 58(6):332-339.

Bobbink, R., K. Hicks, J. Galloway, T. Spranger, R. Alkemade, M. Ashmore, M. Bustamante, S. Cinderby, E. Davidson, F. Dentener, B. Emmett, J.W. Erisman, M. Fenn, F. Gilliam, A. Nordin, L. Pardo, and W. de Vries. 2010. Global assessment of nitrogen deposition effects on terrestrial plant diversity: A synthesis. Ecological Applications 20(1):30-59

Bronson, K.F., and A.R. Mosier. 1993. Nitrous oxide emissions and methane consumption in wheat and corn-cropped systems in northeastern Colorado. In Agricultural Ecosystems Effects on Trace Gases and Global Climate Change, ed. L.A. Harper, A.R. Mosier, J.M. Duxbury, and D.E. Rolston, 133-144. American Society of Agronomy Special Publication No. 55 Madison, WI: American Society of Agronomy.
Brooks, E.S., J. Boll, A.J. Snyder, K.M. Ostrowski, S.L. Kane, J.D. Wulfhorst, L.W. Van Tassell, and R. Mahler. 2010. Long-term sediment loading trends in the Paradise Creek watershed.Journal of Soil and Water Conservation 65(6):331-341, doi:10.2489/jswc.65.6.331.

Bryan, E., T.T. Deressa, G.A. Gbetibouo, and C. Ringler. 2009. Adaptation to climate change in Ethiopia and South Africa: Options and constraints. Environmental Science and Policy 12:413-426.

Cowling, E., J. Galloway, C. Furiness, and J.W. Erisman. 2002. Optimizing Nitrogen Management in Food and Energy Production and Environmental Protection: Report from the Second International Nitrogen Conference, Bolger Center, Potomac, Maryland, October 14-18, 2001 Washington, DC: Ecological Society of America.

Delgado, J.A., and J.K. Berry. 2008. Advances in precision conservation. Advances in Agronomy 98:1-44.

Delgado, J.A., S.J. Del Grosso, and S.M. Ogle. 2010b. ${ }^{15} \mathrm{~N}$ isotopic crop residue cycling studies and modeling suggest that IPCC methodologies to assess residue contributions to $\mathrm{N}_{2} \mathrm{O}-\mathrm{N}$ emissions should be reevaluated. Nutrient Cycling in Agroecosystems 86:383-390.

Delgado, J.A., and R.F. Follett. 2002. Carbon and nutrient cycles. Journal of Soil and Water Conservation 57(6):455-464.

Delgado, J.A., P. Groffman, M.A. Nearing, T. Goddard, D. Reicosky, R. Lal, N. Kitchen, C. Rice, D. Towery, and P. Salon. 2011. Conservation practices to mitigate and adapt to climate change. Journal of Soil and Water Conservation 66(4):118-129.

Delgado, J.A., and A.R. Mosier. 1996. Mitigation alternatives to decrease nitrous oxides emissions and urea-nitrogen loss and their effect on methane flux. Journal of Environmental Quality 25:1105-1111.

Del Grosso, S.J. 2010. Grazing and nitrous oxide. Nature 464:843-844.

Derpsch, R. 2011. Frontiers in conservation tillage and advances in conservation practice. http://www.rolfderpsch.com/notill.htm.

Doran, J.W., and A.J. Jones. 1996. Methods for assessing soil quality. Soil Science Society of America Special Publication 49. Madison, WI: Soil Science Society of America.

Eichholzer, M., and F. Gutzwiller. 1998. Dietary nitrates, nitrites, and $\mathrm{N}$-nitroso compounds and cancer risk: A review of the epidemiologic evidence. Nutrition Reviews 56(4):95-105.

FAO (Food and Agriculture Organization of the United Nations). 2009. Conservation Agriculture. FAO Agriculture and Consumer Protection Department. http://www.fao.org/ag/ca/.

Follett,J.R., R.F. Follett, and W.C. Herz. 2010. Environmental and human impacts of reactive nitrogen. In Advances in Nitrogen Management for Water Quality, ed. J.A Delgado and R.F. Follett, 1-37. Ankeny, IA: Soil and Water Conservation Society.

Follett, R.F., ed. 1989. Nitrogen management and groundwater protection. Amsterdam, The Netherlands: Elsevier.
Fortier, J., D. Gagnon, B. Truax, and F. Lambert. 2010. Nutrient accumulation and carbon sequestration in 6-year-old hybrid poplars in multiclonal agricultural riparian buffer strips. Agriculture, Ecosystems and Environment 137:276-287.

Franzluebbers, A., and R. Follett. 2005. Greenhouse gas contributions and mitigation potential in agricultural regions of North America: Introduction. Soil \& Tillage Research 83:1-8.

Galloway, J.N., J.D. Aber, J.W. Erisman, S.P. Seitzinger, R.W. Howarth, E.B. Cowling, and B.J. Cosby. 2003. The Nitrogen Cascade. BioScience 53(4):341-356.

Galloway, J.N., A.R. Townsend, J.W. Erisman, M. Bekunda, Z. Cai, J.R. Freney, L.A. Martinelli, S.P. Seitzinger, and M.A. Suttan. 2008. Transformation of the nitrogen cycle: Recent trends, questions, and potential solutions. Science 320(May 16):889-892.

Gleick, P.H., R.M. Adams, R.M. Amasino, E. Anders, D.J. Anderson, W.W. Anderson, L.E. Anselin, et al. 2010. Climate change and the integrity of science. Science 328:689-690.

Godfrey, H.C.J., J.R. Beddington, I.R. Crute, L. Haddad, D. Lawrence, J.F. Muir, J. Pretty, S. Robinson, S.M. Thomas, and C. Toulmin. 2010. Food security: The challenge of feeding 9 billion people. Science 327:812-818.

Groffman, P.M., A.J. Gold, and K. Addy. 2000. Nitrous oxide production in riparian zones and its importance to national emission inventories. Chemosphere - Global Change Science 2:291-299.

Groffman, P.M., A.J. Gold, and P.A. Jacinthe. 1998. Nitrous oxide production in riparian zones and groundwater. Nutrient Cycling in Agroecosystems 52:179-186.

Gurian-Sherman,D. 2011. Raising the Steaks. GlobalWarming and Pasture-Raised Beef Production in the United States. Cambridge MA: Union of Concerned Scientists.

Hatfield, J.L., and J.H. Prueger. 2004. Impacts of changing precipitation patterns on water quality. Journal of Soil and Water Conservation 59(1):51-58.

Hill, A.R. 1996. Nitrate removal in stream riparian zones. Journal of Environmental Quality 25:743-755.

IPCC (Intergovernmental Panel on Climate Change). 2006. IPCC guidelines for national greenhouse gas inventories, prepared by the National Greenhouse Gas Inventories Programme, ed. H.S. Eggleston, L. Buendia, K. Miwa, T. Ngara, K. Tanabe. Japan: Institute for Global Environmental Strategies.

Jacobs, T.C., and J.W. Gilliam. 1985. Riparian losses of nitrate from agricultural drainage water. Journal of Environmental Quality 14:272-278.

Jawson, M.D., S.R. Shafer, A.J. Franzluebbers, T.B. Parkin, and R.F. Follett. 2005. GRACEnet: Greenhouse gas Reduction through Agricultural Carbon Enhancement network. Soil \& Tillage Research 83:167-172.

Jha, M.K., K.E. Schilling, P.W. Gassman, and C.F. Wolter. 2010. Targeting land-use change for nitrate-nitrogen load reductions in an agricultural watershed. Journal of Soil and Water Conservation 65(6):342-352. 
Kassam, A., T. Friedrich, F. Shaxon, and J. Pretty. 2009. The spread of conservation agriculture: Justification, sustainability and uptake. International Journal of Agricultural Sustainability 7:252-320.

Kim, D.G., T. Isenhart, T.B. Parkin, R.C. Schultz, and T.E. Loynachan. 2009a. Nitrate and dissolved nitrous oxide in groundwater within cropped fields and riparian buffers. Biogeosciences Discussions 6:651-685.

Kim, D.G., T. Isenhart, T.B. Parkin, R.C. Schultz, T.E. Loynachan, and J.W. Raich. 2009b. Nitrous oxide emissions from riparian forest buffers, warm-season and cool-season grass filters, and crop fields. Biogeosciences Discussions 6:607-650.

Lal, R. 2001. Potential desertification control to sequester carbon and mitigate the greenhouse effect. Climate Change 15:35-72.

Lal, R. 2002. Carbon sequestration in dryland ecosystems of West Asia and North Africa. Land Degradation and Development 13:45-59.

Lal, R. 2003. Soil erosion and the global carbon budget. Environment International 29:437-450.

Lal, R. 2004. Soil carbon sequestration impacts on global climate change and food security. Science 304:1623-1627.

Lal, R. 2005. Forest soils and carbon sequestration. Forest Ecology and Management 220:242-258.

Lal, R. 2010. Carbon sequestration in saline soils. Journal of Soil Salinity and Water Quality. 1:30-40.

Lavado, R.S., J.M. de Paz, J.A. Delgado, and H. RimskiKorsakov. 2010. Evaluation of best nitrogen management practices across regions of Argentina and Spain. In Advances in Nitrogen Management for Water Quality, ed. J.A. Delgado and R.F. Follett. Ankeny, IA: Soil and Water Conservation Society.

Li, X., C. Hu, J.A. Delgado, Y. Zhang, and Z. Ouyang. 2007. Increased nitrogen use efficiencies as a key mitigation alternative to reduce nitrate leaching in North China Plain. Agricultural Water Management 89:137-147.

Lowrance, R., L.S. Altier, J.D. Newbold, R.R. Schnabel, P.M. Groffman, J.M. Denver, D.L. Correll, J.W. Gilliam, J.L. Robinson, R.B. Brinsfield, K.W. Staver, W. Lucas, and A.H. Todd. 1997. Water quality functions of riparian forest buffers in Chesapeake Bay watersheds. Environmental Management 21:687-712.

Lowrance, R., R. Todd, J. Fail, O. Hendrickson, R. Leonard, and L. Asmussen. 1984. Riparian forests as nutrient filters in agricultural watersheds. BioScience 34:374-377.

Mausbach M.J., and A.R. Dedrick. 2004. The length we go: Measuring environmental benefits of conservation practices. Journal of Soil and Water Conservation 59(5):96A-103A.

Meisinger, J.J., and J.A. Delgado. 2002. Principles for managing nitrogen leaching. Journal of Soil and Water Conservation 57(6):485-498.

Mitsch,W.J., J.W. Day, J.W. Gilliam, P.M. Groffman, D.L. Hey, G.W. Randall, and N.M.Wang. 2001. Reducing nitrogen loading to the Gulf of Mexico from the Mississippi
River Basin: Strategies to counter a persistent ecological problem. BioScience 51:373-388.

Montgomery, D.R. 2007. Soil erosion and agricultural sustainability. Proceedings of the National Academy of Sciences 104:13268-13272.

Morton, J.F. 2007. The impact of climate change on smallholder and subsistence agriculture. Procedings of the National Academy of Sciences 104:19680-19685.

Mosier, A., C. Kroeze, C. Nevison, O. Oenema, S. Seitzinger, and O. van Cleemput. 1998. Closing the global $\mathrm{N}_{2} \mathrm{O}$ budget: Nitrous oxide emissions through the agricultural nitrogen cycle - OECD/IPCC/IEA phase II development of IPCC guidelines for national greenhouse gas inventory methodology. Nutrient Cycling in Agroecosystems 52:225-248.

Mosier, A., D. Schimel, D. Valentine, K. Bronson, and W. Parton. 1991. Methane and nitrous-oxide fluxes in native, fertilized and cultivated grasslands. Nature 350:330-332.

Mosier,A.R. 2001. Exchange of gaseous nitrogen compounds between agricultural systems and the atmosphere. Plant and Soil 228:17-27.

Mosier,A.R.,J.W.Doran, and J.R.Freney. 2002. Managing soil denitrification. Journal of Soil and Water Conservation 57(6):505-513.

Nearing, M.A., F.F. Pruski, and M.R. O'Neal. 2004. Expected climate change impacts on soil erosion rates: A review. Journal of Soil and Water Conservation 59(1):43-50.

Nevison, C. 2000. Review of the IPCC methodology for estimating nitrous oxide emissions associated with agricultural leaching and runoff. Chemosphere - Global Change Science 2:493-500.

Oldeman, L.R., and G.W.J.Van Lynden. 1998. Revisiting the GLASOD methodology. In Methods of Assessment of Soil Degradation, ed. R. Lal, W.H. Blum, C. Valentine, and B.A. Stewart, 423-440. Boca Raton, FL: CRC Press.

Osmond, D.L. 2010. USDA water quality projects and the National Institute of Food and Agriculture Conservation Effects Assessment Project watershed studies. Journal of Soil and Water Conservation 65(6):142A-146A, doi:10.2489/jswc.65.6.142A.

Peterjohn, W.T., and D.L. Correll. 1984. Nutrient dynamics in an agricultural watershed: Observations on the role of a riparian forest. Ecology 65(5):1466-1475.

Ramanathan, V., and Y. Xu. 2010. The Copenhagen Accord for limiting global warming: Criteria, constraints and available avenues. Proceedings of the National Academy of Sciences of the United States of America 107(18):8055-8062.

Reay, D.S., A.C. Edwards, and K.A. Smith. 2009. Importance of indirect nitrous oxide emissions at the field, farm and catchment scale. Agriculture, Ecosystems and Environment 133:163-169.

Reay, D.S., K.A. Smith, A.C. Edwards, K.M. Hiscock, L.F. Dong, and D.B. Nedwell. 2005. Indirect nitrous oxide emissions: Revised emission factors. Environmental Sciences 2:153-158.
Reay, D.S., K.A. Smith, and A.C. Edwards. 2003. Nitrous oxide emission from agricultural drainage waters. Global Change Biology 9:195-203.

Richardson, C.W., D.A. Bucks, and E.J. Sadler. 2008. The Conservation Effects Assessment Project benchmark watersheds: Synthesis of preliminary findings. Journal of Soil and Water Conservation 63(6):590-604, doi:10.2489/jswc.63.6.590.

Robertson, G.P., and P.M. Vitousek. 2009. Nitrogen in agriculture: Balancing an essential resource. Annual Review of Energy and the Environment 34:97-125.

Ruddiman, W.F. 2003. The anthropogenic greenhouse era began thousands of years ago. Climatic Change 61:261-293.

Sawamoto, T., Y. Nakajima, M. Kasuya, H. Tsuruta, and K. Yagi. 2005. Evaluation of emission factors for indirect $\mathrm{N}_{2} \mathrm{O}$ emission due to nitrogen leaching in agroecosystems. Geophysical Research Letters 32:L03403.

Shrestha, R.K., D.A.N. Ussini, and R. Lal. 2009. Terrestrial carbon sequestration potential in reclaimed mine ecosystems to mitigate the greenhouse effect. In Soil Carbon Sequestration and the Greenhouse Effect, ed. R. Lal and R.F. Follett, 321-346. Madison, WI: Soil Science Society of America.

Silici, L. 2010. Conservation Agriculture and Sustainable Crop Intensification in Lesotho, 61. Rome, Italy: Food and Agriculture Organization of the United Nations (FAO).

Snyder, C.S., T.W. Bruulsema, and T.L. Jensen. 2007. Greenhouse gas emissions from cropping systems and the influence of fertilizer management-a literature review. Norcross, GA: International Plant Nutrition Institute. http://www.ipni.net/ipniweb/portal.nsf/0/ d27fe7f63bc1fcb3852573ca0054f03e/\$FILE/ IPNI\%20BMPs\%20\&\%20GHG.pdf.

Snyder, C.S., T.W. Bruulsema, T.L. Jensen, and P.E. Fixen. 2009. Review of greenhouse gas emissions from crop production systems and fertilizer management effects. Agriculture, Ecosystems and Environment 133:247-266.

Taghizadeh-Toosi, A., T.J. Clough, L.M. Condron, R.R. Sherlock, C.R. Anderson, and R.A. Craigie. 2011. Biochar incorporation into pasture soil suppresses in situ nitrous oxide emissions from ruminant urine patches. Journal of Environmental Quality 40:468-476.

Thiombiano, L., and M. Meshack. 2009. Scaling-up Conservation Agriculture in Africa: Strategy and Approaches, 31. Addis Ababa, Ethiopia: Food and Agriculture Organization of the United Nations (FAO) Sub Regional Office for Eastern Africa.

Tomer, M.D. 2010. How do we identify opportunities to apply new knowledge and improve conservation effectiveness? Journal of Soil and Water Conservation 65(4):261-265, doi:10.2489/jswc.65.4.261. 
USDA NRCS (Natural Resources Conservation Service). 2010. Agriculture Secretary Vilsack Announces New Steps to Meet the Challenge of Climate Change. USDA Office of Communications. Release No. 0642.10. Washington, DC: USDA Natural Resources Conservation Service.http://www.nrcs.usda.gov/news/ releases/2010/cig_ghg_12.09.10.html.

USEPA (US Environmental Protection Agency). 1989. Federal Register. 54 FR 22062, 22 May. Washington, DC: US Environmental Protection Agency.

Verdin, J., C. Funk, G. Senay, and R. Choularton. 2005. Climate science and famine early warning. Philosophical Transations of the Royal Society 360:2155-2168.

Vitousek, P.M., J.D. Aber, R.W. Howarth, G.E. Likens, P.A. Matson, D.W. Schindler, W.H. Schlesinger, and D.G. Tilman. 1997. Human alteration of the global nitrogen cycle: Sources and consequences. Ecological Applications 73(3):737-750.

Walter, T., M. Dosskey, M. Khanna, J. Miller, M. Tomer, and J. Weins. 2007. The science of targeting within landscapes and watersheds to improve conservation effectiveness. In Managing Agricultural Landscapes for Environmental Quality: Strengthening the Science Base, ed. M. Schnepf and C. Cox, 63-89. Ankeny, IA: Soil and Water Conservation Society.

World Bank.2006.Sustainable Land Management:Challenges, Opportunities and Trade-offs. Agricultural and Rural Development. Washington, DC: The International Bank for Reconstruction and Development/ The World Bank. http://siteresources.worldbank.org/INTARD/ Resources/Sustainable_Land_Management_ebook.pdf. 